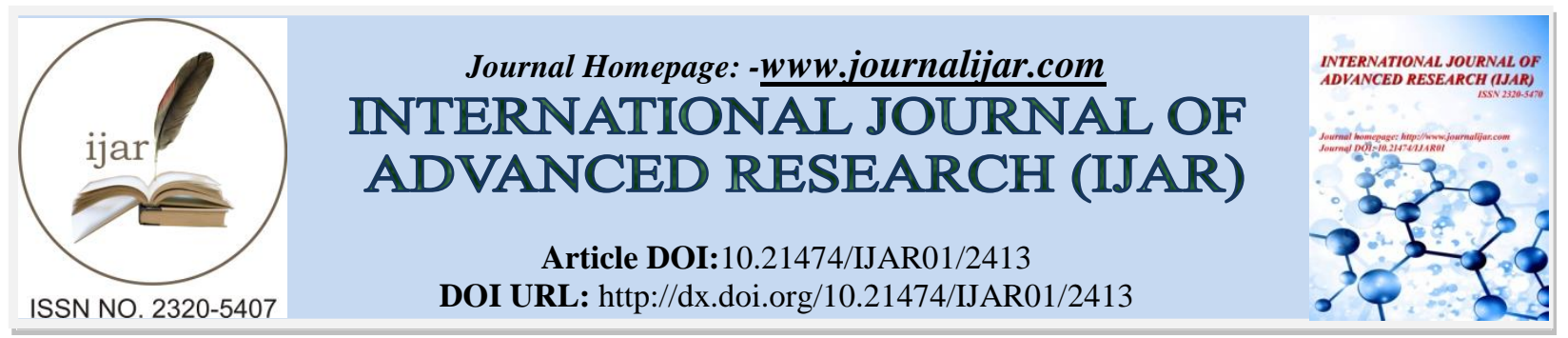

RESEARCH ARTICLE

\title{
REMOVAL OF HEAVY METALS FROM WASTE WATER BY USING A NATURAL AND BIODEGRADABLE ADSORBENT BASED ON PRUNUS AVIUM L. STEMS AS ADSORBENTS
}

Ali Mcheik, Wassef El Khatib, Akram Hijazi*, Kamal Hariri, Mohamad Reda, Hassan Rammal Doctoral School of Science and Technology, Research Platform for Environmental Science (PRASE), Lebanese University, Lebanon.

\section{Manuscript Info}

Manuscript History

Received: 20 October 2016

Final Accepted: 22 November 2016

Published: December 2016

Key words:-

Prunus avium; Copper (II); Adsorption; Langmuir and Freundlich isotherm models.

\section{Abstract}

The objective of this study was to investigate the possibility of using Lebanese Prunus avium stems as an alternative adsorbent for the removal of copper ion from aqueous solutions. Different parameters such as the effect of initial metal ion concentration, $\mathrm{pH}$, adsorbent dose, contact time and temperature were studied. Maximum adsorption capacity $(89.5 \%)$ of copper ion was obtained at $\mathrm{pH} 10$, an initial Copper concentration $150 \mathrm{mg} / \mathrm{l}$ after $1 \mathrm{~h}$ and at $25{ }^{\circ} \mathrm{C}$. FT-IR analysis is pointed out the involvement of amine $\left(-\mathrm{NH}_{2}\right)$ and carboxylic $(-\mathrm{COOH})$ group in the adsorption process. The adsorption isotherm was better described by a Freundlich model rather than by a Langmuir model. Based on these obtained results, it can be concluded that the stems of Prunus avium are effective as an alternative adsorbent for toxic copper ions remediation in waste water.

Copy Right, IJAR, 2016,. All rights reserved.

\section{Introduction:-}

Heavy metals are one of the most important wide spread environmental problems in water resources [ ${ }^{\mathrm{i}}$ ]. These metals are toxic since they are non biodegradable [ii], so they must be removed. Copper is one of the top 6 deadliest and toxic materials known, it is most commonly found in $2^{+}$oxidation state in nature [iii . It is frequently used in industrial processes such as alloys, painting, electroplating, smelting, batteries and mining industry. When absorbed into the body in quantities greater than ten milligrams, adverse effects are acute and if over a long period of time, can be fatal [iii]. Copper causes damage to kidneys, cardiac tissue, bones and is thought to be a carcinogen [ ${ }^{\mathrm{iv}}$ ]. Symptoms of copper exposure are increased loss of small proteins in the urine, salivation, choking, vomiting, metallic taste, loss of sense of smell, joint pain and others. Different physiochemical techniques are being used to reduce the toxicity of copper from waste water such as ion exchange, chemical precipitation, reverse osmosis, electro dialysis, membrane filtration, flotation and activated carbon adsorption $\left[{ }^{\mathrm{v}}\right]$, but they have incomplete removal and high material cost.

Several researches are done on natural adsorbent to remove copper from aqueous solutions such as plants material like nut husk $\left[{ }^{\mathrm{vi}}\right]$, juniper bark and wood $\left[{ }^{\mathrm{vii}}\right]$, orange peel $\left[{ }^{\mathrm{viii}}\right]$, orange waste $\left[{ }^{\mathrm{ix}}\right]$, wheat stem $\left[{ }^{\mathrm{x}}\right]$, rice husk $\left[{ }^{\mathrm{xi}}\right]$, agricultural waste biomass $\left[{ }^{\mathrm{xii}}\right]$, wheat straw $\left[{ }^{\mathrm{xiii}}\right]$, coconut shell $\left[{ }^{\mathrm{xiv}}\right]$ and sugar beet pulp $\left[{ }^{\mathrm{xv}}\right]$. In the present work, for the first time, the stems of the Lebanese Prunus avium has been used as adsorbent to remove Cu (II) from waste water by varying the experimental conditions such as contact time, initial metal ion concentration, temperature and $\mathrm{pH}$, parameters could be applied in the reduction of copper pollution in the environment. 


\section{Material and Methods:-}

The raw Prunus avium (sweet cherry) stems were collected from a local Lebanese plantation. The stems were thoroughly rinsed with water, then, they were dried at room temperature for 10 days. After that, the dried stems were grinded to a fine powder to get a size of $0.25 \mathrm{~mm}$.

\section{Chemicals}

The stock solution was prepared by dissolving $0.15 \mathrm{~g}$ of $\mathrm{CdCl}_{2} . \mathrm{H}_{2} \mathrm{O}$ in $1 \mathrm{~L}$ deionised water. All the required working solutions were prepared by diluting the stock solution with deionised water. Samples for Fourier transform infrared (FT-IR) were prepared by diluting the adsorbent to $5 \%$ in $\mathrm{KBr}$ and cast in disks for analysis. Analysis of standards and simulated samples was done using an AA-140 atomic absorption spectrometer (AAS).

\section{Experimental methods}

Batch experiments were carried out using a series of Erlenmeyer flask of $50 \mathrm{~mL}$ capacity. Batch experiments were prepared to study the effect of initial $\mathrm{Cu}$ (II) concentration, $\mathrm{pH}$, contact time, adsorbent dose and temperature on adsorption of the $\mathrm{Cu}$ (II) ions from its solution. All the adsorption experiments were carried out at room temperature except where the effect of temperature was being investigated. The initial $\mathrm{pH}$ was adjusted with $\mathrm{HNO}_{3}(1 \mathrm{M})$ or $\mathrm{NaOH}(1 \mathrm{M})$ solutions.

\section{Biosorption isotherms}

Adsorption isotherms are essential for understanding the mechanism of an adsorption system. Since they represent the amount of compounds adsorbed on a surface as a function of concentration at a constant temperature [ $\left.{ }^{\mathrm{xv}}\right]$. Two isotherms models were tested:

1. Freundlich isotherm: is the well-known earliest relationship which describes the adsorption process. It can be applied to non-ideal sorption on heterogeneous surfaces as well as multilayer sorption $\left[{ }^{\mathrm{xvii}}\right]$. This isotherm is expressed by the following linear equation:

Log $\mathrm{qe}=\log \mathrm{kF}+\frac{1}{n} \log \mathrm{Ce}$

Where $K F$ is the Freundlich constant related to the bonding energy $(\mathrm{L} / \mathrm{mg}), 1 / \mathrm{n}$ is the heterogeneity factor and $\mathrm{n}$ $(\mathrm{g} / \mathrm{L})$ is a measure of the deviation from linearity of adsorption. Freundlich equilibrium constants were determined from the plot of $\log q e$ versus $\log \mathrm{Ce}$ (Figure 1), basis on the linear of Freundlich equation (3). Where the n value indicates the degree of non-linearity between solution concentration and adsorption as follows: if $n=1$, the adsorption is linear. If $\mathrm{n}<1$, the adsorption is a chemical process. If $\mathrm{n}>1$, the adsorption is a physical process. The $\mathrm{n}$ value in Freundlich equation was found to be 0.983 for P. avium. Since $\mathrm{n}$ is greater than 1, this indicates the physical biosorption of $\mathrm{Cu}$ (II) onto $P$. avium. The values of correlation coefficients $R^{2}$ are done as a measure of goodness of fit of the experimental data to the isotherm models [ $\left.{ }^{\text {xviii }}\right]$.

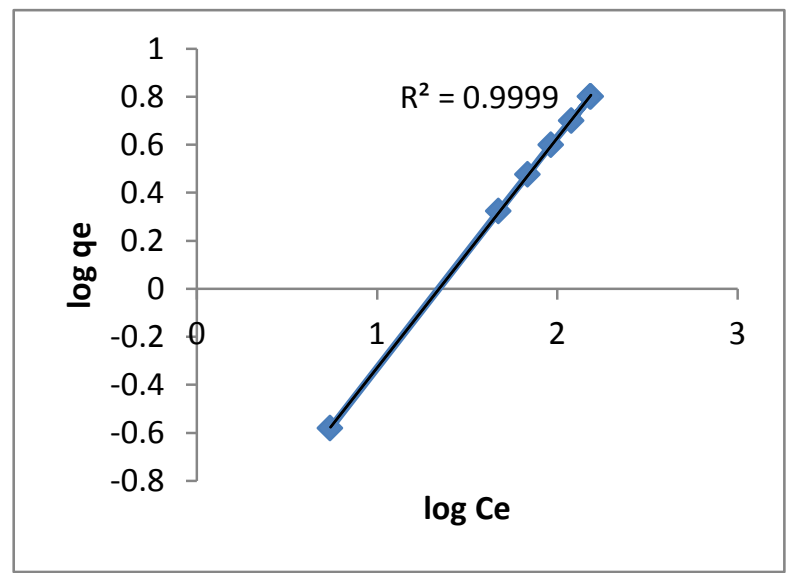

Figure 1:-Freundlich isotherm for $\mathrm{Cu}$ (II) biosorption into Prunus avium stems

2. Langmuir isotherm: assumes the formation of an adsorbed solute monolayer on a uniform surface with a finite number of adsorption sites [xix $]$. When a site is filled, no further sorption can take place at that site. Therefore the surface will reach a saturation point where the maximum 
adsorption of the surface will be achieved. The linear form of the Langmuir isotherm model is described as:

$$
\frac{C_{e}}{q_{e}}=\frac{1}{K_{L} q_{\max }}+\frac{1}{q_{\max }} C e
$$

Where $\mathrm{q}_{\max }$ is the maximum adsorption capacity $(\mathrm{mg} / \mathrm{g}$ ) and $K L$ is the Langmuir constant related to the energy of adsorption $(1 / \mathrm{g})$. Values of Langmuir parameters $\mathrm{q}_{\max }$ and $K L$ were calculated from the slope and intercept of the linear plot of Ce/qe versus $C e$ as shown in Figure 2. Values of $\mathrm{q}_{\max }, K_{L}$ and correlation coefficient $R^{2}$ are listed in Table 1. These values for $P$. avium biosorbent indicated that Langmuir model describes the biosorption phenomena favorable.

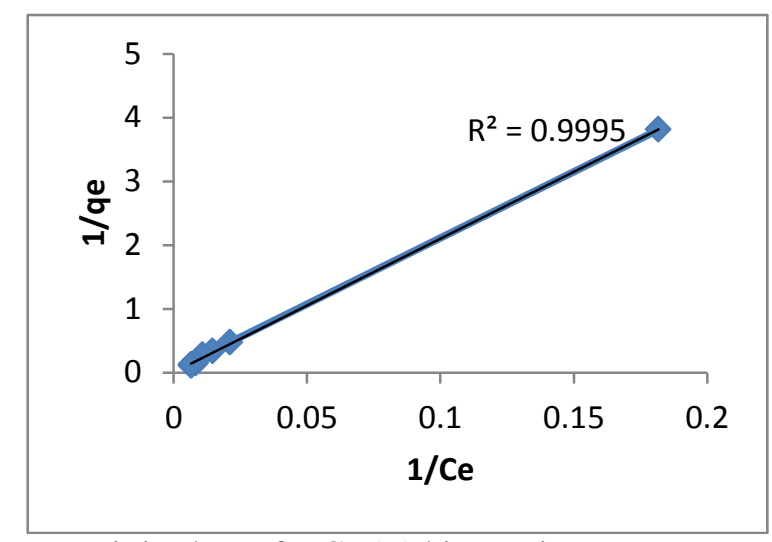

Figure 2:- Langmuir isotherm for $\mathrm{Cu}$ (II) biosorption onto Prunus avium stems.

The essential characteristics of the Langmuir isotherm parameters can be used to predict the affinity between the sorbate and sorbent using separation factor or dimensionless equilibrium parameter, $R L$ expressed as in the following equation:

$$
R_{L}=\frac{1}{\left(1+K_{L} C_{o}\right)}
$$

Where Co is the initial concentration of sorbate $(\mathrm{mg} / \mathrm{l})$ and $\mathrm{KL}$ is the Langmuir constant $(\mathrm{L} / \mathrm{mg})$. There are four possible values for $\mathrm{R}_{\mathrm{L}}$ : to be irreversible $\left(R_{L}=0\right)$, favorable $\left(0<R_{L}<1\right)$, linear $\left(R_{L}=1\right)$ or unfavorable $\left(R_{L}>1\right)\left[{ }^{\mathrm{xx}}\right]$. The $R_{L}$ was found to be 0.9937 for concentration of $25-600 \mathrm{mg} / \mathrm{L}$ of Cu (II). They are in the range of 0-1 which indicates the favorable biosorption.

\section{Results and Discussion:-}

When $P$. avium stems powder was tested for its ability to adsorb $\mathrm{Cu}$ (II) ion from aqueous solution, initial $\mathrm{pH} 6$ was used for most experiments. The effects of the following experimental parameters ( $\mathrm{pH}$, initial concentration, contact time, temperature and the adsorbent dosage) on adsorption were studied. The percentage of the uptake or adsorption of $\mathrm{Cu}$ (II) was calculated using the following equation:

$$
\% \text { Removal }=\frac{\mathrm{C}_{\mathrm{i}}-\mathrm{C}_{\mathrm{f}}}{\mathrm{C}_{\mathrm{i}}} \times 100
$$

Where $\mathrm{Ci}=$ initial concentration $(\mathrm{mg} / \mathrm{l}) ; \mathrm{Cf}=$ final concentration $(\mathrm{mg} / \mathrm{l})$. The adsorption capacity of $\mathrm{Cu}$ (II) is the concentration of $\mathrm{Cu}$ (II) over the adsorbent mass and it was calculated based on the mass balance principle according to the following equation:

$$
\mathrm{q}_{\mathrm{m}} \text { (adsorption capacity) }=\frac{\mathrm{C}_{0}-\mathrm{C}_{\mathrm{f}}}{\mathrm{m}} \times \mathrm{V}
$$

$\mathrm{q}_{\mathrm{m}}=$ amount of $\mathrm{Cu}$ (II) per dry weight of $P$. avium; $\mathrm{V}=$ volume of the reaction mixture (L); $\mathrm{m}=$ mass of adsorbent used $(\mathrm{g}) ; \mathrm{C}_{\mathrm{o}}=$ initial concentration $(\mathrm{mg} / \mathrm{L})$ and $\mathrm{C}_{\mathrm{f}}=$ final concentration $(\mathrm{mg} / \mathrm{L})$. 


\section{FT-IR and XRF analysis of adsorbent:-}

The FT-IR spectrum presented in the figure 3 was used to investigate the functional groups present on the P. avium stems that could be responsible for the removal of heavy metal species [ $\left.{ }^{x i}\right]$. The spectrum of the adsorbent was measured within the range of $4000-400 \mathrm{~cm}^{-1}$ wave number. The comparison of the FT-IR spectra has been done before and after loading with $\mathrm{Cu}$ (II). The $P$. avium stems show a number of absorption peaks that reflects its complex nature. Two peaks at $3513 \mathrm{~cm}^{-1}$ and $3436 \mathrm{~cm}^{-1}$ are due to the presence of N-H bond stretching (primary amine). A broad peak at $3292 \mathrm{~cm}^{-1}$ is due to the existence of OH group. The absorption peak at $2924 \mathrm{~cm}^{-1}$ could be assigned to $\mathrm{C}-\mathrm{H}$ stretching vibration, $1736 \mathrm{~cm}^{-1}$ to ester carbonyl, $1608 \mathrm{~cm}-1$ to $\mathrm{C}=\mathrm{C}, 1520 \mathrm{~cm}^{-1}$ to N-H, $1066 \mathrm{~cm}^{-1}$ to $\mathrm{C}-\mathrm{O}$.

After adsorption, a broad peak at $3466 \mathrm{~cm}^{-1}$ corresponds to the overlapping of $\mathrm{OH}$ and $\mathrm{NH}$ peak. This phenomenon may be attributed to the water molecule directly interacting with amide.

After $\mathrm{Cu}$ (II) binding, a change of peak position occurs $\left(3437-3435 \mathrm{~cm}^{-1}, 3292-3290 \mathrm{~cm}^{-1}, 1736-1738 \mathrm{~cm}^{-1}, 1253\right.$ $\left.1252 \mathrm{~cm}^{-1}, 1066-1056 \mathrm{~cm}^{-1}, 824-811 \mathrm{~cm}^{-1}, 536-558 \mathrm{~cm}^{-1}\right)$.

The shift in the wave number corresponds to the change in the energy of the functional groups that indicates the existence of $\mathrm{Cu}$ binding process done on the surface of $P$. avium stems powder [xii].

The XRF spectrum has been done to show the metals composition in the stems of $P$. avium. It was consisting of $\mathrm{Ca}$, $\mathrm{Fe}, \mathrm{Ni}, \mathrm{Nb}$, Mo among others as shown in figure 4.

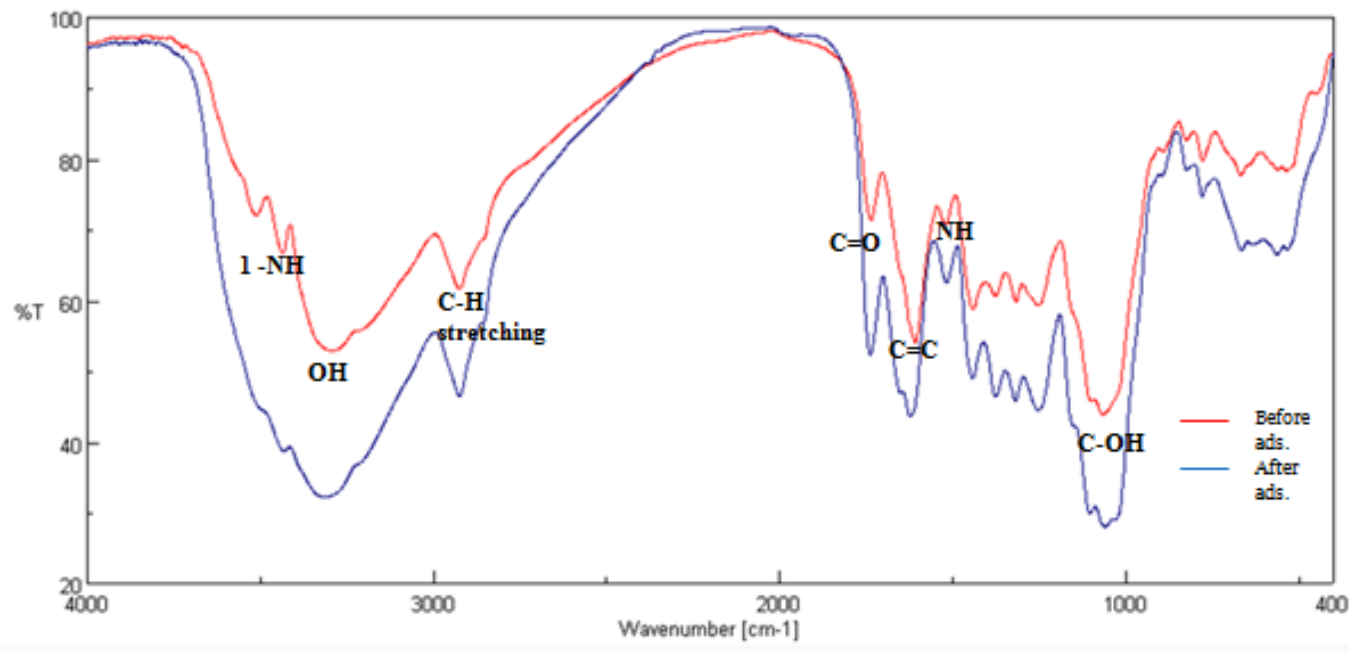

Figure 3:- FT-IR spectrum of stems of Prunus avium before and after adsorption 


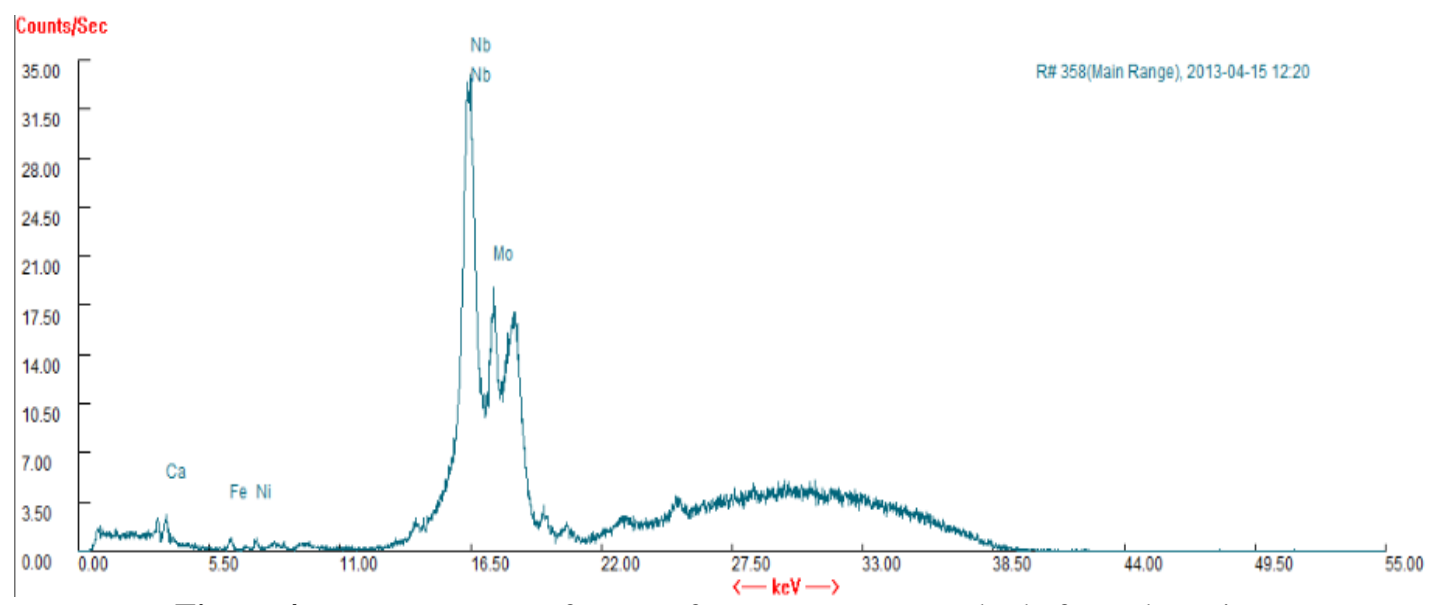

Figure 4:- XRF spectrum of stems of Prunus avium powder before adsorption

\section{The effect of metal ion concentration on adsorption}

$0.5 \mathrm{~g}$ of the adsorbent was shacked with $50 \mathrm{ml}$ of varying concentrations $(25,150,300,400$ and $600 \mathrm{mg} / \mathrm{l})$ of $\mathrm{Cu}$ (II) solution. The mixture was continuously agitated at $25 \pm 2{ }^{\circ} \mathrm{C}$ with a shaker at $400 \mathrm{rpm}$. The $\mathrm{pH}$ of the solution was adjusted to a $\mathrm{pH}$ 6. After the established contact time (1 hour) was reached, the suspension was filtered in 2 steps: first by Buchner filtration then by $0.45 \mu \mathrm{m}$ filter. After that, the final concentration of $\mathrm{Cu}$ (II) in the filtrate was determined using AAS. The adsorbed amount was determined from the difference between the initial and residual concentrations of $\mathrm{Cu}$ (II) in the liquid phase.

\section{The effect of pH on adsorption of $\mathrm{Cu}$ (II) ions}

The $\mathrm{pH}$ of the aqueous solution is an important parameter which controls the $\mathrm{Cu}$ (II) adsorption process, as it affects the surface charge of the adsorbents and the degree of ionization [ ${ }^{\mathrm{xiii}}$ ]. Figure 5 shows clearly that $P$. avium stems exhibit maximum $\mathrm{Cu}$ (II) removal at $\mathrm{pH} 4$, which were rather acidic. At low $\mathrm{pH}$ (below 3), the increased number of protons in solution on this biosorbent often refuses the formation of links between $\mathrm{Cu}$ (II) ions and the active site. At moderate $\mathrm{pH}$ values ( 3 to 6 ) the number of $\mathrm{H}^{+}$becomes fewer, allowing more $\mathrm{Cu}$ (II) ions to be adsorbed to the active sites $\left.{ }^{[x i v}\right]$. At $\mathrm{pH}$ lower than 8 , the dominant forms of $\mathrm{Cu}$ was $\mathrm{Cu}(\mathrm{II})$; while $\mathrm{Cu}(\mathrm{OH})_{2}$ was present as precipitate at $\mathrm{pH}$ greater than 8 . Based on these results, the $\mathrm{Cu}$ was bound to active surface by $\mathrm{O}^{2-}$ ions and released $\mathrm{H}^{+}$into the solution, thereby decreasing the $\mathrm{pH}\left[{ }^{\mathrm{xx}}\right]$.

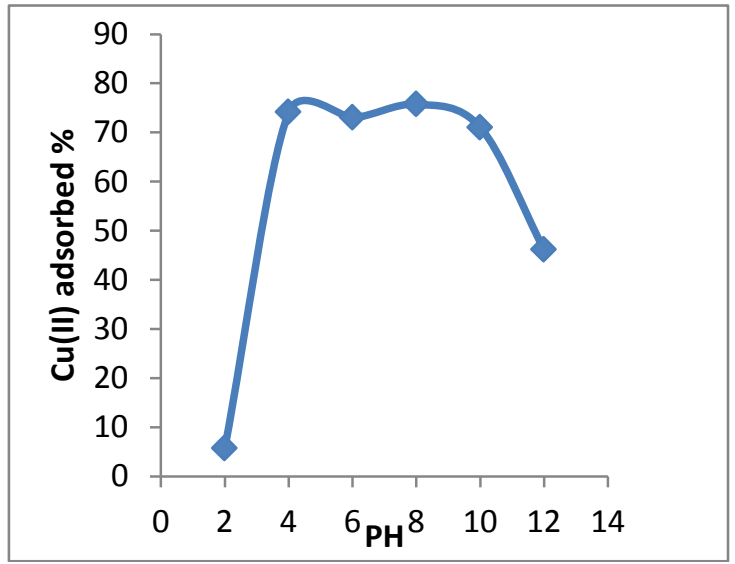

Figure 5:- Effect of $\mathrm{pH}$ on adsorption

\section{The effect of contact time on the $\mathrm{Cu}$ (II) adsorption}

The effect of contact time on the adsorption of $\mathrm{Cu}$ (II) from its solution is shown in figure 6. There is a general increase in the $\%$ adsorption of $\mathrm{Cu}$ (II) with time. However, the adsorption slowed down after 2 hours, where the maximum removal efficiency is $67.9 \%$. This could possibly be the time required for the equilibrium to be established. 


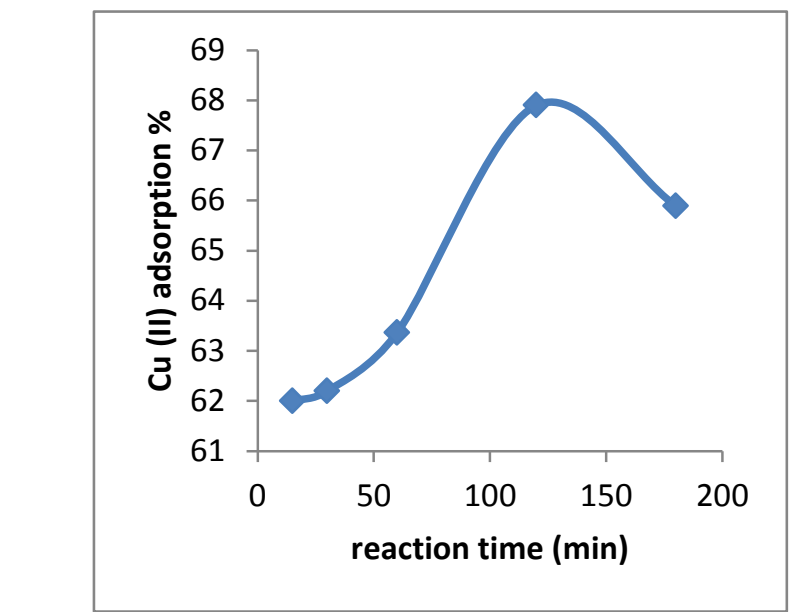

Figure 6:- Effect of contact time on the adsorption of $\mathrm{Cu}$ (II)

The effect of temperature on the metal adsorption

The adsorption of $\mathrm{Cu}$ (II) from aqueous solutions at different temperatures was investigated. Samples were subjected to temperatures ranged from 0 to $66^{\circ} \mathrm{C}$. Figure 7 shows that the adsorption capacity reached a maximum at $25{ }^{\circ} \mathrm{C}$ and thereafter it decreased gradually. The maximum adsorption efficiency of $3.0855 \mathrm{mg} / \mathrm{g}(65.1 \%)$ occurred at 25 ${ }^{\circ} \mathrm{C}$. However, overheating might result in desorption kinetics dominating.

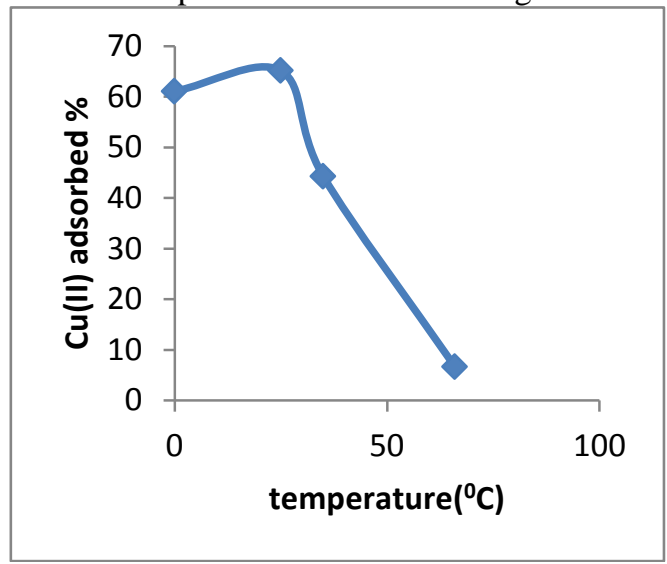

Figure 7:- Effect of temperature on $\mathrm{Cu}$ (II) adsorption

The effect of the adsorbent dose on the removal of $\mathrm{Cu}$ (II) ions:-

The adsorbent dosage is another important parameter because it influences the extent of metal uptake from the solution and thus the effect as shown in figure 8. The percentage removal efficiency of $\mathrm{Cu}$ (II) decreased from $71.08 \%$ to $46.64 \%$ when the adsorbent dosage increased from 0.2 to $1 \mathrm{~g}$. The adsorption capacity decreased sharply with the increasing of adsorbent dosage. These results may due to the overlapping of the adsorption sites as a result of overcrowding of adsorbent particles. Moreover, the high adsorbent dosage could impose a screening effect of the dense outer layer of the cells, thereby shielding the binding sites from metal. 


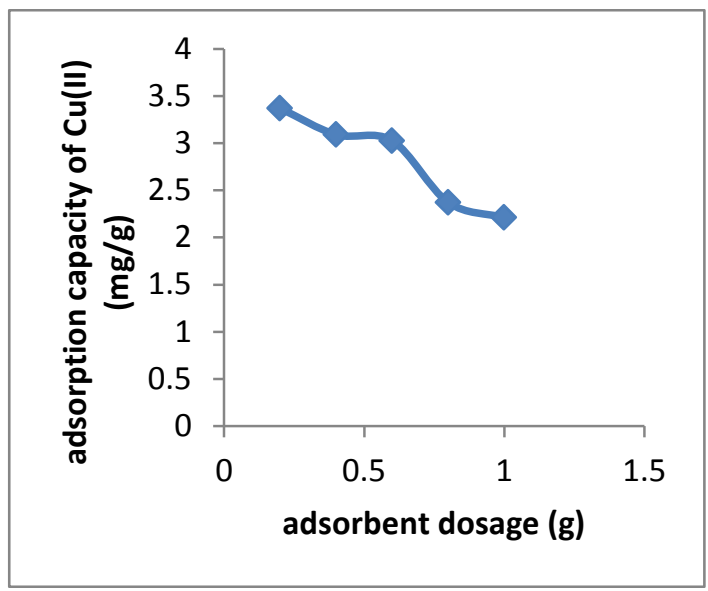

Figure 8:- Effect of adsorbent dose on adsorption capacity

\section{Competition among heavy metals in waste waters:-}

The metals of interest are usually found with a number of other metals. Prunus avium stems can effectively bind a number of heavy metal ions but it would be doubtful that all ions have been equality bound. Figures (a-e) show the percentage of adsorption of each ion in the presence of other. The general binding affinity of the $P$. avium for the metals studied, in order decreasing affinity is $\mathrm{Cu}$ (II) $>\mathrm{Cd}$ (II) $\approx \mathrm{Pb}$ (II) $>\mathrm{Cr}$ (VI) (fig. e). While it is clear that some of the metal ions compete with one another for bark binding sites, it is of interest to note that the binding of $\mathrm{Pb}$ (II) is relatively unaffected by other metals [ $\left.{ }^{\mathrm{xxvi}}\right]$. The difference in the adsorption behavior of $\mathrm{Pb}$ (II) and $\mathrm{Cd}$ (II) compared $\mathrm{Cr}$ (VI) and $\mathrm{Cu}$ (II) may also be explained by the different affinity of metal ions for the donor atoms present in the structure of $P$. avium stems.

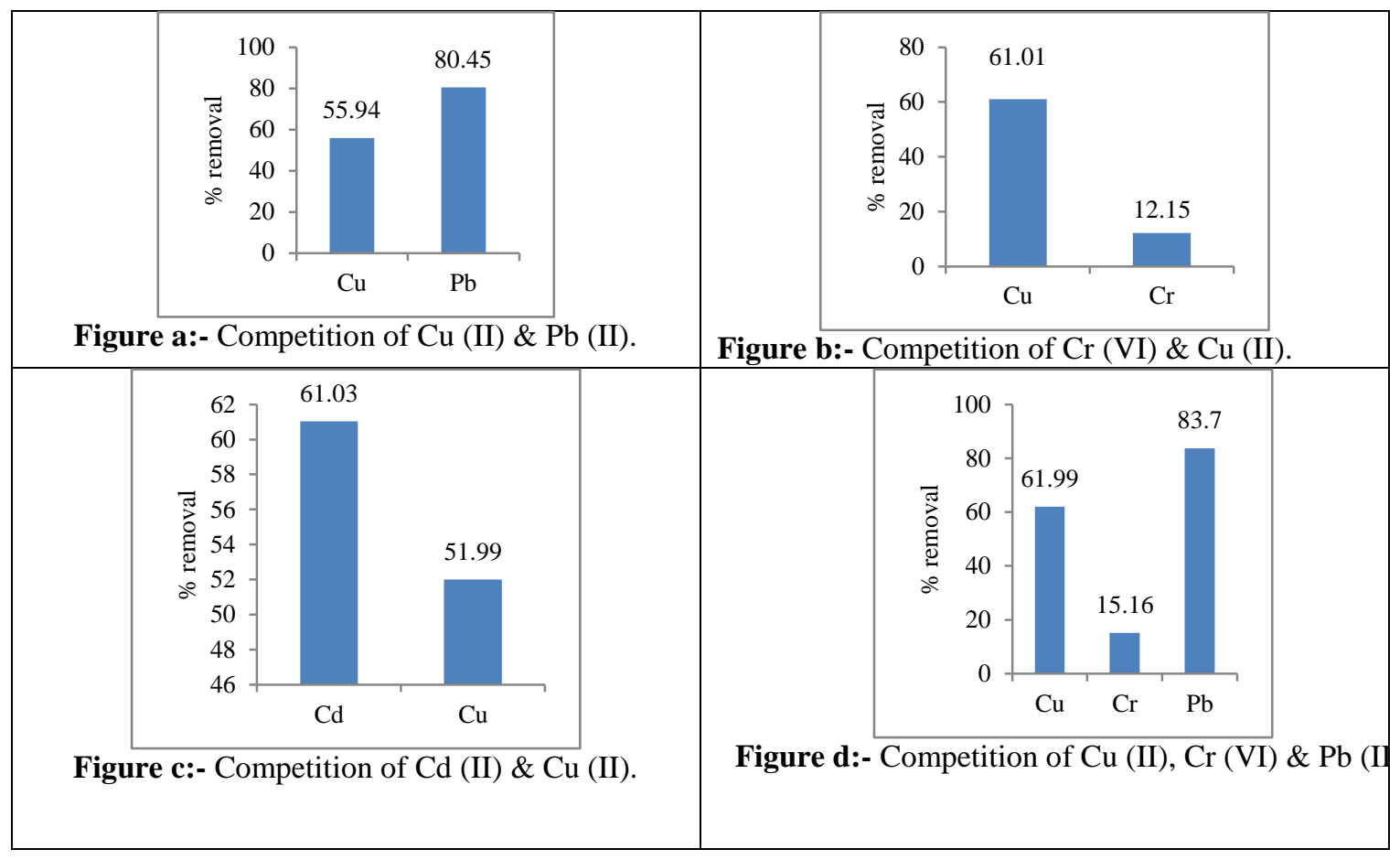




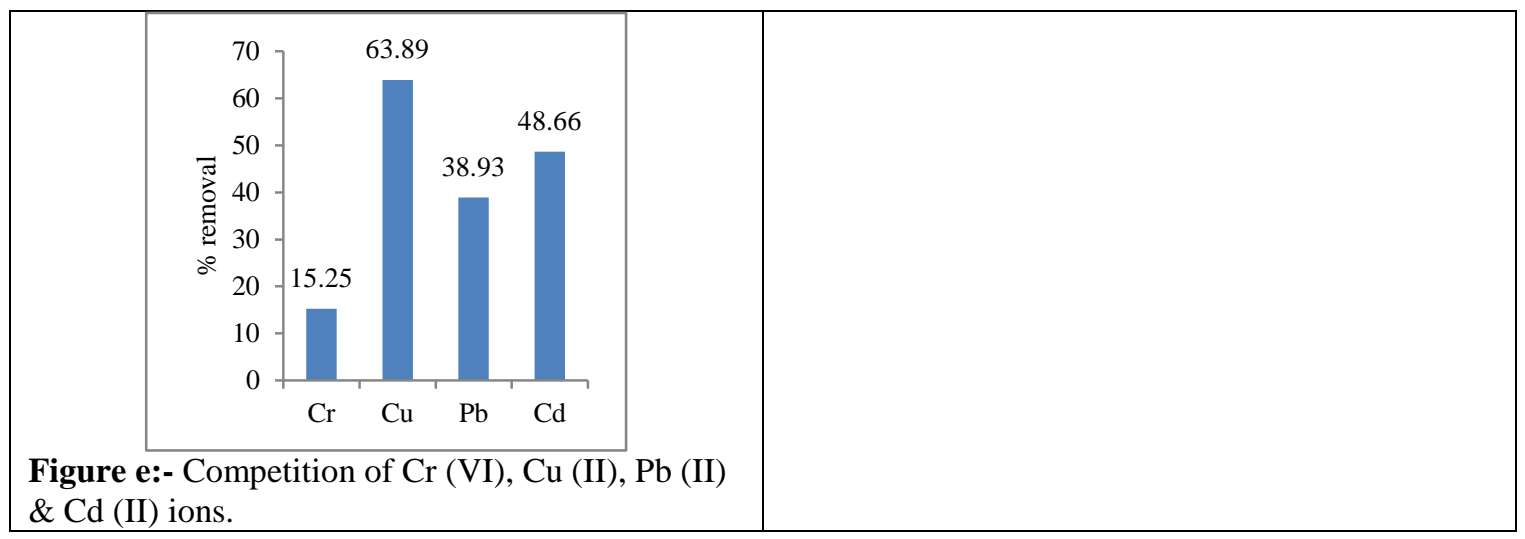

Figures a-e: Percentage of adsorption of each ion in the presence of other

The values of correlation coefficient $\mathrm{R}^{2}$ are regarded as a measure of goodness of fit of experimental data to isotherm model. Therefore, from table 1 for $\mathrm{Cr}$ (IV) and $\mathrm{Pb}$ (II) we can see that Langmuir gave a better fit than Freundlich isotherm, while for $\mathrm{Cu}$ (II) and Cd (II) Freundlich gave a better fit than Langmuir isotherm.

Table 1:- Langmuir constants for studied heavy metals ion biosorption by $P$. avium stems

\begin{tabular}{|c|c|c|c|c|c|}
\hline & $\mathbf{K}_{\mathbf{L}}$ & $\mathbf{q}_{\max }$ & $\mathbf{R}_{\mathbf{L}}$ & $\mathbf{R}^{\mathbf{2}}$ & Type of adsorption \\
\hline $\mathbf{C r}$ (VI) & 0.000542 & 100 & 0.996 & 0.9997 & Favorable \\
\hline $\mathbf{P b}$ (II) & 0.05223 & 9.572718 & 0.561 & 0.9999 & Favorable \\
\hline $\mathbf{C u}$ (II) & 0.00482 & 10 & 0.974 & 0.9995 & Favorable \\
\hline $\mathbf{C d}$ (II) & 0.00505 & 10 & 0.983 & 0.9937 & Favorable \\
\hline
\end{tabular}

\section{Conclusion:-}

This study investigated the adsorption of $\mathrm{Cu}$ (II) ions from aqueous solutions onto dried Prunus avium stems that is dependent on biosorption process such as initial metal ions concentration, $\mathrm{pH}$, adsorbent dose, and temperature and contact time. To provide best correlation for biosorption of $\mathrm{Cu}$ (II) ions onto $P$. avium stems, Freundlich and Langmuir biosorption isotherm were demonstrated. From this study, it was observed that stems of $P$. avium stems can be used as an alternative low cost, eco-friendly and effective adsorbent for treatment of waste water containing $\mathrm{Cu}$ (II) ions. Other heavy metals adsorbed by stems of $P$. avium are under study.

\section{Acknowledgement:-}

This work was supported by Central Administration of the Lebanese University and Doctoral School of Science and Technology (EDST), Research Platform for Environmental Science (PRASE), Lebanese University.

1. Benhima, H., Chiban, M., Sinan, F., Seta, P., 2008. "Removal of lead and copper ions from aqueous sodium by adsorption onto micro-particles of dry plants". Colloids and Surfaces B: Biointerfaces, 61:10-16.

2. Shafaghat, A., Salimi, F., Valiei, M., Salehzadeh, J., Shafaghat, M., 2012. "Removal of heavy metals (Pb ${ }^{2+}$, $\mathrm{Cu}^{2+}$ and $\mathrm{Cr}^{3+}$ ) from aqueous solutions using five plants materials". African Journal of Biotechnology, 11(4):852-855.

3. Longe, J.L. 2005."Copper poisoning."The Gale Encyclopedia of Alternative Medicine.Vol. 1, 2nd edition.

4. Bortman, M., Brimblecombe P., Cunningham M A., 2003. "Copper." Environmental Encyclopedia.Vol. 1, 3rd edition.

5. Doyurum S., Celik A., 2006. "Pb (II) and Cd (II) removal from aqueous solutions by olive cake". Journal of Hazardeous Material 138 (1): 22-28.

6. Okieimen, F.E., Okuundla, E.V., Ogbeifun, D.E., 1991. "Sorption of copper and lead ions on modified ground nut husks". J. Chem. Technol. Biotechnol. 51: 97-103.

7. Shin E.W., Karthikeyan K.G., Mandla A., Tshabalala M.A., 2007. Adsorption mechanism of copper on juniper bark and wood. Bioresource Technology 98: 588-594. 576. 
8. Li, X., Tang, Y., Xuan, Z., Liu, Y., Fang Luo, F., 2007. Study on the preparation of orange peel cellulose adsorbents and biosorption of $\mathrm{Cd}^{2+}$ from aqueous solution. Sep. Purif. Technol. 55: 69-75.

9. Perez-Marin, A.B., Zapata, V.M., Ortuno, J.F., Aguilar, M., Saez, J., Llorens, M., 2007. Removal of copper from aqueous solutions by adsorption onto orange waste. Journal of Hazardeous Material 139: 122-131.

10. Tan, G.Q., Xiao, D., 2009. Adsorption of copper ion from aqueous solution by ground wheat stems. Journal of Hazardeous Material 164: 1359-1363.

11. Kumar, U., Bandyopadhyay, M., 2006. Sorption of copper from 537 aqueous solution using pretreated rice husk. Bioresource Technology 538 97: 104-110.

12. Garg, U., Kaur, M.P., Jawa, G.K., Sud, D., Garg, V.K., 2008. 518 Removal of copper (II) from aqueous solutions by adsorption on 519 agricultural waste biomass. Journal of Hazardeous Material 154: 1149-1157.

13. Dang, V.B.H., Doan, H.D., Dang-Vu, T., Lohi, A., 2009. Equilibrium and kinetics of biosorption of copper(II) and copper(II) ions by wheat straw. Bioresource Technology 100: 211-219.

14. Pino, G.H., Souza de Mesquita, L.M., Torem, M.L., Pinto, G.A.S., 2006. Biosorption of copper by green coconut shell powder. Miner. Eng. 19 380-387.

15. Pehlivan, E., Yanik, B.H., Ahmetli, G., Pehlivan, M., 2008. Equilibrium isotherm studies for the uptake of copper and lead ions onto sugar beet pulp. Bioresource Technology 99: 3520 - 3527.

16. O.S. Amuda, A.A. Giwa, I.A. Bello, "Removal of heavy metal from industrial waste water using modified activated coconut shell carbon", Biochem. Eng. J., vol. 36 (2), p. 174-181, 2007.

17. E. Malkoc,Y. Nuhoglu, M. Dundar, "Adsorption of chromium (VI) on pomace-An olive industry waste: Batch and column studies", J. Hazard Mater, vol. 138 (1), p. 142-151, 2006.

18. E. Malkoc,Y. Nuhoglu, M. Dundar, "Adsorption of chromium (VI) on pomace-An olive industry waste: Batch and column studies", J. Hazard Mater, vol. 138 (1), p. 142-151, 2006.

19. M. Nidá Salem, M. Ahlam, A.K.L. Farhan, M. Awwad, "Biosorption of Copper (II) from Aqueous Solutions by PrunusaviumLeaves", American Journal of Environmental Engineering, vol. 2(5), p. 123-127, 2012.

20. H.B. Senturk, D. Ozdes, C. Duran, "Biosorption of rhodamine 6G from aqueous solutions onto almond shell (Prunusdulcis) as a low cost biosorbent", Desalination, vol. 252 , p. 81-87, 2010.

21. Wahab, M.A., S. Jellali, N. Jedidi, "Ammonium biosorption onto sawdust: FTIR analysis, kinetics and adsorption isotherms modeling", Bioresource Technology 101:5070-5075, 2010.

22. L. Orenatribe, K. Kwon, C. Trout, et al.," Molecular orbital theory study on surface complex structures of glyphosate on goethite: calculation of vibrational frequencies", Environ. Sci. Technol, Vol. 40, p. 3836-3841, 2006.

23. Aksu, Z., 2005. "Application of biosorption for the removal of organic pollutants: a review". Process Biochem, 40: 997-1026.

24. Shafaghat, A., Salimi, F., Valiei, M., Salehzadeh, J., Shafaghat, M., 2012. "Removal of heavy metals $\left(\mathrm{Pb}^{2+}\right.$, $\mathrm{Cu}^{2+}$ and $\mathrm{Cr}^{3+}$ ) from aqueous solutions using five plants materials". African journal of Biotechnology 11(4): 852-855.

25. Gaballah I., Kilbertus G., 1998. "Recovery of heavy metal ions through decontamination of synthetic solutions and industrial effluents using modified barks", J. Geochem. Explor., 62: 241-286.

26. Gloaguen V, Morvan H.J., 1997. "Removal of heavy metal ions from aqueous solution by modified barks", Environmental Sci Health, 32(4): 901-912. 